\title{
Correction to: Comparison of biomass estimates from multiple stratification approaches in a swept area method for Pacific saury Cololabis saira in the western North Pacific
}

\author{
Midori Hashimoto $^{1} \cdot$ Hideaki Kidokoro $^{2} \cdot$ Satoshi Suyama $^{2} \cdot$ Taiki Fuji $^{1} \cdot$ Hiroomi Miyamoto $^{2} \cdot$ Miyako Naya $^{2} \cdot$ \\ Dharmamony Vijai $^{3} \cdot$ Yasuhiro Ueno ${ }^{1} \cdot$ Toshihide Kitakado $^{4}$
}

Published online: 30 March 2021

(c) The Author(s) 2021

\section{Correction to: Fisheries Science (2020) 86:445-456 https://doi.org/10.1007/s12562-020-01407-3}

The article "Comparison of biomass estimates from multiple stratification approaches in a swept area method for Pacific saury Cololabis saira in the western North Pacific", written by Midori Hashimoto, Hideaki Kidokoro, Satoshi Suyama, Taiki Fuji, Hiroomi Miyamoto, Miyako Naya, Dharmamony Vijai, Yasuhiro Ueno and Toshihide Kitakado was originally published Online First without Open Access. After publication in volume 86 , issue 3 , page $445-456$ the author decided to opt for Open Choice and to make the article an Open Access publication. Therefore, the copyright of the article has been changed to (C) The Author(s) 2021 and the article is forthwith distributed under the terms of the Creative Commons Attribution 4.0 International License (https://creat ivecommons.org/licenses/by/4.0/), which permits use, sharing, adaptation, distribution and reproduction in any medium

The original article can be found online at https://doi.org/10.1007/ s12562-020-01407-3.

Midori Hashimoto

mhashimoto@affrc.go.jp

1 Yokohama Field Station, Fisheries Stock Assessment Center, Fisheries Resources Institute, JapanFisheries Research and Education Agency, 2-12-4 Fukuura, Kanazawa, Yokohama, Kanagawa 236-8648, Japan

2 Hachinohe Field Station, Fisheries Stock Assessment Center, Fisheries Resources Institute, Japan Fisheries Research and EducationAgency, 25-259, Shimomekurakubo, Same, Hachinohe, Aomori 031-0841, Japan

3 National Centre for Biological Science, Tata Instituteof Fundamental Research, Bellary Road, Bangalore, Karnataka 560065, India

4 Tokyo University of Marine Science and Technology, 4-5-7 Konan, Minato-ku, Tokyo 108-8477, Japan or format, as long as you give appropriate credit to the original author(s) and the source, provide a link to the Creative Commons licence, and indicate if changes were made. The original article has been corrected.

Open Access This article is licensed under a Creative Commons Attribution 4.0 International License, which permits use, sharing, adaptation, distribution and reproduction in any medium or format, as long as you give appropriate credit to the original author(s) and the source, provide a link to the Creative Commons licence, and indicate if changes were made. The images or other third party material in this article are included in the article's Creative Commons licence, unless indicated otherwise in a credit line to the material. If material is not included in the article's Creative Commons licence and your intended use is not permitted by statutory regulation or exceeds the permitted use, you will need to obtain permission directly from the copyright holder. To view a copy of this licence, visit http://creativecommons.org/licenses/by/4.0/.

Publisher's Note Springer Nature remains neutral with regard to jurisdictional claims in published maps and institutional affiliations. 